\title{
Attitude towards Computers among Primary School Teachers in Kenya: A Case of Siongiroi Divison, Bomet County.
}

\author{
Paul K. Rotich ${ }^{1 *}$, Richard K Ronoh ${ }^{2}$ and Joseph M Mubichakani ${ }^{3}$ \\ ${ }^{1}$ Department of Science Education, University of Eldoret, ${ }^{2}$ Department of Computer Science, Kibabii \\ University, KENYA \\ ,3joemukuyuni@gmail.com
}

\begin{abstract}
In the quest of equipping the pupils with the digital skills required to work in the $21^{\text {st }}$ century knowledge economy, the government of Kenya plans to provide laptops to every primary school class one pupil. If this is to be successful, the question of teacher attitude towards computers is central. This paper presents the results of a survey to study and examine the attitudes of the primary school teachers towards computers. In addition, the study investigated the effects of age, gender, teaching experience, level of education, and computer experience on computer attitude. Data for this study was collected among 114 primary school teachers from Siongiroi Division, Bomet County, Kenya. Measurement tools used was the Computer Attitude Scale (CAS) by Loyd and Gressard (1984). The data acquired was analyzed using descriptive statistics and an analysis of variance (ANOVA).The results indicated that although the teachers have positive attitudes towards computers, they have low confidence level in using the computers. The study also found that the primary school teachers, despite their differences in gender, age, teaching experience and level of education, did not differ significantly (in statistical sense) in their computer attitude. Since teachers portray positive attitudes toward computers, efforts should be geared towards reinforcing the existing positive attitudes. This study highlights the importance of uplifting teachers' confidence level in using computers.
\end{abstract}

Keywords: Computer attitude; Computer Attitude Scale (CAS); confidence level; primary school teachers

\section{Introduction}

According to Yushau (2006), computers are gradually becoming the most powerful tools of all human inventions with applications spreading to almost all aspects of human endeavor. One aspect in which computers have had a significant impact is education. Globally, computers have been used in education for more than four decades, and they have become an integral part of the entire educational system. There is no doubt that a valuable asset a teacher may have is to have access to a computer because of its versatility. With multimedia capabilities, computers have the capabilities of appealing to our eyes, ears and feeling. Therefore, they can widen and enrich the content and scope of our educational experiences.

During the campaigns ahead of Kenya's March 2013 elections, the Jubilee team manifesto highlighted the promise to provide laptops to every primary school class one pupil. The proponents of this project continued to say that it was a noble idea targeting the birth of a new tech-savvy generation that will be compliant with the dictates of this era. They said that the ability of pupils to master new technologies would have a critical impact on the country's future global competitiveness. They also said that the Millennium Development Goals (MDGs) and Kenya's Vision 2030 are anchored on technology and science. They argued that if Rwanda, with a Gross Domestic Product of 644 billion shillings, has managed a laptop revolution titled One Laptop per Child 
(OLPC), Kenya, the East Africa's leading economy with a GDP of KShs. 3.1 trillion will definitely manage it also.

However, some Kenyans, including Jubilee supporters, thought that the promise was just one of those enticing electioneering slogans that would quickly be side-lined in due course. But after forming the Jubilee government, the president reiterated both on the inauguration day and at the Parliament opening ceremony (Kenyatta, 2013), that the laptops project for class one pupils was still on the table and indeed money has already been allocated in the national budget. He further stated that the government had also allocated funds for the project in its second year budget. Though there have been delays in the tendering process, the government seemed determined to keep its school laptop promise. No doubt the nation is waiting with bated breath to see a fulfilment of the promises as envisioned in the Jubilee manifesto. The children are on a high to receive the laptops and join their peers in Rwanda and the developed world in becoming computer literate through eLearning.

For proper and effective use of computer technologies in instruction, teacher attitude towards computers is an important factor (Kadijevich, 2002; Griffin, 1988). Different researchers have given different but somehow related definitions of the word 'attitude'. Aiken (1980) described attitudes as "learned predispositions to respond positively or negatively to certain objects, situations, concepts, or persons". Gibson, Ivancevich, and Donnelly defined attitude as "a positive or negative feeling or mental state of readiness, learned and organized through experience, that exerts specific influence on a person's response to people, object and situation" (Gibson et al., 1991; p. 70). More specifically, Rosenberg defined attitude as the way an individual feels about and is disposed towards some "object" (Rosenberg, 1960). Advocating the school of thought of Krech, Crutchfield, and Ballackey (1962), Triandis (1971) suggested that attitudes consist of: (1) affective, (2) cognitive, and (3) behavioral components. The affective component of attitudes is the emotional or "feeling" which includes statements of likes or dislikes about certain things. Accordingly, in the context of computers a statement such as "I like computers" or "I hate computers" is a measure of the affective component of attitudes. The cognitive part of attitudes includes statements of beliefs. For example, a certain individual may hold a belief that computers can significantly increase the quality of his or her output. The behavior part of attitude is what the individual actually does or intends to do. Thus, a statement like "I will use this new software to prepare the requested report" is a statement of intended behavior. Therefore, attitudes consist of what individuals feel (affective), belief (cognitive), and what they plan to do (behavioral). On the other hand, the second school of thought, represented by Fishbein and Ajzen (1975) argues that attitude measurement should be concerned solely with the affective domain.

This study adopted an instrument called Computer Attitude Scale (CAS), developed by Loyd and Loyd (1985), with different components that claim to account for the four components of attitudes. The components of CAS are: computer anxiety, computer confidence, computer liking, and computer usefulness. Computer anxiety refers to fear of computers or the tendency of a person to be uneasy, apprehensive, and phobic towards current or future use of computers in general (Igbaria, 1993; Cambre and Cook 1985; Loyd and Loyd, 1985). An example of a statement used to measure computer anxiety is "computers make me feel uncomfortable." Computer confidence refers to the ability to use or learn about computers (Gressard and Loyd, 1986). For example, a statement like "I am sure I could do work with computers" could be used to measure confidence about using computers. Computer confidence has been shown to be closely related to computer anxiety, with an inverse relationship (Loyd and Loyd, 1985). Computer liking refers to liking or enjoying working with computers. For example, "I would like working with computers" could be a statement used to measure computer liking. Anxiety and liking represent the affect (feelings) part of attitude (Thompson et al., 1991).Computer usefulness refers to the degree of perceived usefulness of using computers for present and future work. An example of a statement used to measure computer usefulness is "I will use computers in many ways in my life." This subscale partly measures the cognition (beliefs) part of attitude (Thompson et al., 1991).

Previous correlation studies have long forecasted that the use of computers in education would very much depend on how well teachers integrate them in everyday activities (Yushau, 2006). If teachers are to adopt 
computer technologies, they must have the right kind of attitudes toward the computers. And therefore, the question of teacher attitude toward computers is central to any successful use of computers in education (Loyd \& Loyd, 1985; Kluever, Lam, Hoffman, Green, \& Swearingen, 1994; Yuen \& Ma, 2001). The importance of attitudes and beliefs for learning to use new technologies is widely acknowledged (De Young and Spence, 2004; Loyd and Gressard, 1984; Ray, Sormunen, and Harris, 1999; Saade and Galloway, 2005). It has been found that teachers initially resisted the use of computers in education. As a matter of fact, the term "computer phobia" and "computer anxiety" were coined and entered in the literature vocabulary due to teacher (not student) resistance to computer use (Yushau, 2006). The causes of this resistance according to Nickerson (1981) are not unconnected with feelings of stupidity, fear of obsolescence, fear of the unfamiliar, and the thought that computers have a dehumanizing effect. Studies have shown that computer anxiety, lack of confidence, and lack of enjoyment influence both the acceptance of computers and their use as a teaching and learning tool (Gressard \& Loyd, 1986; Smith \&Kotrlik, 1990; Woodrow, 1991; Fletcher \& Deeds, 1994).

Indeed both researchers and educators have emphasized the role that teachers' attitudes toward computers play as a crucial factor in the successful use of computers in the teaching and learning. To ensure that computers are successfully integrated in teaching and learning and eventually, teachers' commitment are required. The teachers are the custodians of the ICT project, and will actually do the groundwork in terms of equipping pupils with these very vital IT skills.

This study is mainly motivated by the fact that attitudes of primary school teachers toward computers are still not widely explored in the context of Kenyan schools. It is especially interesting to know what these teachers really think of, expect from, fear and know about these new technologies. It was against this background that this research was envisioned.

\section{Research Objectives}

The objectives of this study were;

1. To examine and measure the attitude of primary school teachers toward computers.

2. To investigate the effects of the teachers' age, gender, teaching experience, level of education, and computer experience on computer attitude.

\section{Methodology}

The data for this study were gathered by means of questionnaire survey. The study was conducted in Siongiroi Division, Bomet County, Kenya. Table 1 describes the profile of the sample. The questionnaires were distributed among the teachers in 15 schools by the researchers themselves. The teachers were to fill their responses and hand them in before the researchers left the stations. All respondents were guaranteed confidentiality of individual responses. Only 114 responses were returned with a response rate of $81 \%$. The responses were coded in a spreadsheet, and exported for statistical analysis using Statistical Package for Social Science (SPSS) version 20. 
Table 1: Profile of the sample

\begin{tabular}{|c|c|c|c|}
\hline Teacher characteristics & Group & frequency & percentage \\
\hline \multirow{6}{*}{ Age (yrs) } & 22 or less & 7 & 6.1 \\
\hline & $23-29$ yrs & 22 & 19.3 \\
\hline & $30-29 \mathrm{yrs}$ & 51 & 44.7 \\
\hline & $40-49$ yrs & 27 & 23.7 \\
\hline & $50 \mathrm{yrs}$ and above & 7 & 6.1 \\
\hline & Total & 114 & 100.0 \\
\hline \multirow{3}{*}{ Sex } & Male & 57 & 50.0 \\
\hline & Female & 57 & 50.0 \\
\hline & Total & 114 & 100.0 \\
\hline \multirow{5}{*}{ Teaching Experience } & Less than 2 yrs & 10 & 8.8 \\
\hline & $2-5 \mathrm{yrs}$ & 27 & 23.7 \\
\hline & $6-10 \mathrm{yrs}$ & 27 & 23.7 \\
\hline & More than 10 yrs & 50 & 43.9 \\
\hline & Total & 114 & 100.0 \\
\hline \multirow{6}{*}{ Qualification } & Form 4 leaver & 8 & 7.0 \\
\hline & P1 certificate & 50 & 43.9 \\
\hline & Diploma & 37 & 32.5 \\
\hline & Degree & 16 & 14.0 \\
\hline & Masters & 3 & 2.6 \\
\hline & Total & 114 & 100.0 \\
\hline \multirow{6}{*}{ Computer Experience } & Never & 24 & 21.1 \\
\hline & 1 wk -3 months & 23 & 20.2 \\
\hline & 4 months - less than $1 \mathrm{yr}$ & 19 & 16.7 \\
\hline & $1 \mathrm{yr}-2 \mathrm{yrs}$ & 29 & 25.4 \\
\hline & More than 2 yrs & 19 & 16.7 \\
\hline & Total & 114 & 100.0 \\
\hline \multirow{5}{*}{ Current course pursued } & None & 69 & 60.5 \\
\hline & Diploma & 19 & 16.7 \\
\hline & Degree & 23 & 20.2 \\
\hline & Masters & 3 & 2.6 \\
\hline & Total & 114 & 100.0 \\
\hline
\end{tabular}

The instrument used in this study was Computer Attitude Scale (CAS) by Loyd and Gressard (1984). CAS is an instrument measuring different aspects of computer attitude. CAS consists of four subscales: Computer Anxiety, Computer Confidence, Computer Usefulness, and Computer Liking. The aim of the computer anxiety subscale is to assess the fear while dealing with computers, while that of computer confidence is to assess the confidence in the ability of dealing with computers. Computer liking subscale assesses the enjoyment of dealing with computers, and computer usefulness assesses the perception their use in preparation of presentable material for their lessons and generally in addressing the challenge of organizing teaching instructions. All the questions present statements of attitude towards computers and their use.

\section{Results and Discussions}

The Computer Attitude Scale (CAS) used in this research is a Likert-type instrument. It consisted of forty items with each subscale consisting of ten questions. The participants indicated the degree to which they agreed with the statement on a four-point scale, with "agree strongly" on one end and "disagree strongly" on the other. Each response is given a value of 1 to 4 , with 4 indicating a more positive attitude towards computers. It is worth noting that the participant that answered all the questions has a maximum score of 40 and a minimum of 10 score for each subscale. The total score of the 40 questions is a general measure of attitude toward computers. Thus, the total score values can range from a low of 40 to a high of 160 . For this test, higher the scores indicate more positive attitudes toward computers. Participants with attitude score of 25 and above in each subscale of CAS and 100 and above in the total score (general computer attitude) are considered to have 
positive attitude. The results of this study suggest (as indicated by Table 2) that primary school teachers in Bomet County have fairly positive attitudes towards computer. This is clearly seen in their mean scores of over 33 out of 40in all the four subscales and also in the general attitude with a mean score of over 137 out of 160. This means that teachers portrayed positive attitudes toward computers. This is quite encouraging and these results may be good news to the Jubilee government since it may need such teachers to implement the laptop project.

Table 2. Summary of the means and standard deviation of the subscales and the general computer attitude scale

\begin{tabular}{|l|r|r|}
\hline Subscale & Mean & Standard deviation \\
\hline Computer Anxiety & 34.26 & 4.30 \\
\hline Computer Confidence & 33.28 & 4.15 \\
\hline Computer Liking & 34.72 & 4.41 \\
\hline Computer Perceived Usefulness & 35.49 & 3.96 \\
\hline General Computer Attitude & 137.75 & 13.24 \\
\hline
\end{tabular}

In particular, the attitude of the teachers towards perceived usefulness of computer is the highest with a mean of more than 35 out of 40. This is an indication that the perception of the primary school teachers towards computer is more of a positive tool that can enhance teaching and learning process. However, as the results indicate, the teachers scored the least in computer confidence subscale. This means that the teachers need to learn more on how to operate the computers.

The effect of age, gender, computer experience, level of education, and teaching experience on computer attitude

Many studies have shown the significant effect of age and computer experience on attitudes towards computers (Loyd \& Gressard, 1984; To replicate the findings in these studies, ANOVA analyses where done with age, gender, level of education, computer experience, level of education and teaching experience as factors and general computer attitude as criteria. Results indicated that computer experience had a significant influence on the general computer attitude among the teachers. Results also indicate that there was significant difference in general attitude among the teachers who were pursuing different courses. However, age, gender, level of education and teaching experience did not show any significant influence of the general computer attitudes (Tables 3 - 8).

Table 3. Age difference and computer attitude

\begin{tabular}{|c|c|c|c|c|c|c|c|c|c|c|}
\hline & \multicolumn{6}{|c|}{ ANOVA STATISTICS } & \multicolumn{4}{|c|}{ DESCRIPTIVES } \\
\hline $\begin{array}{l}\text { Independent } \\
\text { variable }\end{array}$ & & $\begin{array}{l}\begin{array}{l}\text { Sum } \\
\text { squares }\end{array} \text { of } \\
\end{array}$ & d.f & $\begin{array}{l}\text { Mean } \\
\text { squares }\end{array}$ & $\begin{array}{l}\mathrm{F} \\
\text { value }\end{array}$ & $\begin{array}{l}\mathrm{P}- \\
\text { value }\end{array}$ & & & & \\
\hline \multirow{7}{*}{ Age } & \multirow{3}{*}{$\begin{array}{l}\text { Between } \\
\text { group }\end{array}$} & \multirow[t]{3}{*}{541.198} & \multirow[t]{3}{*}{4} & \multirow[t]{3}{*}{135.299} & \multirow[t]{7}{*}{0.765} & \multirow[t]{7}{*}{0.550} & Group & $\mathbf{N}$ & Mean & S. D \\
\hline & & & & & & & 22 or less & 7 & 131.86 & 14.83 \\
\hline & & & & & & & $23-29 \mathrm{yrs}$ & 22 & 135.23 & 15.16 \\
\hline & \multirow{3}{*}{$\begin{array}{l}\text { Within } \\
\text { group }\end{array}$} & \multirow[t]{3}{*}{19273.925} & \multirow[t]{3}{*}{109} & \multirow[t]{3}{*}{176.825} & & & $30-29 y r s$ & 51 & 139.06 & 12.40 \\
\hline & & & & & & & $40-49 \mathrm{yrs}$ & 27 & 139.22 & 9.80 \\
\hline & & & & & & & $\begin{array}{l}50 \text { yrs and } \\
\text { above }\end{array}$ & 7 & 136.43 & 22.20 \\
\hline & Total & 19815.123 & 113 & & & & Total & 114 & $\mathbf{1 3 7 . 5 4}$ & 13.24 \\
\hline
\end{tabular}

Table 3 shows the computer attitude among the primary school teachers with different age groups. Results of descriptive statistics in Table 3 indicate that the primary school teachers, in all the age groups, had a general compute attitude of more than 131 out of 160 . Despite this, ANOVA statistic indicates that there was no significant difference ( $\mathrm{p}$ value of 0.550 ) in general computer attitude with the various age groups. That is, the differences noted in means are not significant in statistical sense. 
Table 4. Gender difference and computer attitude

\begin{tabular}{|c|c|c|c|c|c|c|c|c|c|c|}
\hline & \multicolumn{6}{|c|}{ ANOVA STATISTICS } & \multicolumn{4}{|c|}{ DESCRIPTIVES } \\
\hline $\begin{array}{l}\text { Independent } \\
\text { variable }\end{array}$ & & $\begin{array}{l}\text { Sum } \\
\text { squares }\end{array}$ & d.f & $\begin{array}{l}\text { Mean } \\
\text { squares }\end{array}$ & $\begin{array}{ll}\mathrm{F} & - \\
\text { value }\end{array}$ & $\begin{array}{ll}\mathrm{P} & - \\
\text { value }\end{array}$ & & & & \\
\hline \multirow[t]{4}{*}{ Gender } & $\begin{array}{l}\text { Between } \\
\text { group }\end{array}$ & 11.368 & 1 & 11.368 & \multirow[t]{4}{*}{0.064} & \multirow[t]{4}{*}{0.800} & Group & $\mathrm{N}$ & Mean & S. D \\
\hline & \multirow[t]{2}{*}{ Within group } & \multirow[t]{2}{*}{19803.754} & \multirow[t]{2}{*}{112} & \multirow[t]{2}{*}{176.819} & & & Male & 57 & 138.07 & 12.63 \\
\hline & & & & & & & Female & 57 & 137.44 & 13.93 \\
\hline & Total & 19815.123 & 113 & & & & Total & 114 & 137.75 & 13.24 \\
\hline
\end{tabular}

Table 4 above shows the difference in computer attitude among male and female primary school teachers. Descriptive statistics in the Table 4 indicates that although Male teachers had a higher mean of 138.07 than the female teachers (mean of 137.75), ANOVA statistics indicates that the differences were not significant ( $\mathrm{F}$ value of 0.064 and $p-$ value of 0,800 ). Therefore, the data evidenced no reliable differences in computer attitude between teachers of gender.

Table 5. Computer Experience difference and computer attitude

\begin{tabular}{|c|c|c|c|c|c|c|c|c|c|c|}
\hline & \multicolumn{6}{|c|}{ ANOVA STATISTICS } & \multicolumn{4}{|c|}{ DESCRIPTIVES } \\
\hline $\begin{array}{l}\text { Independent } \\
\text { variable }\end{array}$ & & $\begin{array}{ll}\begin{array}{l}\text { Sum } \\
\text { squares }\end{array} & \text { of } \\
\end{array}$ & d. $f$ & $\begin{array}{l}\text { Mean } \\
\text { squares }\end{array}$ & $\begin{array}{l}\text { F }- \\
\text { value }\end{array}$ & $\begin{array}{l}\mathrm{P} \\
\text { value }\end{array}$ & & & & \\
\hline \multirow{7}{*}{$\begin{array}{l}\text { Computer } \\
\text { experience }\end{array}$} & \multirow{3}{*}{$\begin{array}{l}\text { Between } \\
\text { Groups }\end{array}$} & \multirow[t]{3}{*}{1826.717} & \multirow[t]{3}{*}{4} & \multirow[t]{3}{*}{456.679} & \multirow[t]{7}{*}{2.767} & \multirow[t]{7}{*}{0.031} & Group & $\mathbf{N}$ & Mean & S. D \\
\hline & & & & & & & Never & 24 & 132.71 & 12.75 \\
\hline & & & & & & & 1 wk -3 months & 23 & 135.87 & 14.26 \\
\hline & \multirow[t]{3}{*}{$\begin{array}{l}\text { Within } \\
\text { Groups }\end{array}$} & \multirow[t]{3}{*}{17988.406} & \multirow[t]{3}{*}{109} & \multirow[t]{3}{*}{165.031} & & & $\begin{array}{l}4 \text { months - less } \\
\text { than } 1 \mathrm{yr}\end{array}$ & 19 & 136.26 & 16.48 \\
\hline & & & & & & & $1 \mathrm{yr}-2 \mathrm{yrs}$ & 29 & 139.69 & 9.62 \\
\hline & & & & & & & More than 2 yrs & 19 & 144.95 & 11.30 \\
\hline & Total & 19815.123 & 113 & & & & Total & 114 & 137.75 & 13.24 \\
\hline
\end{tabular}

Table 5 shows the differences in computer attitude among the primary school teachers with different computer experiences. Descriptive statistics in Table 5 reveal that there seems to be a direct kind of relationship between computer experience and computer attitude. This means that teachers with more computer experience have more positive computer attitude. The ANOVA statistics in Table 5 indicate that indeed there is a significant difference ( $\mathrm{p}$ - value of 0.031 ) in computer attitude with computer experience at significant level of 0.05 .

Table 6. Level of education difference and computer attitude

\begin{tabular}{|c|c|c|c|c|c|c|c|c|c|c|}
\hline & \multicolumn{6}{|c|}{ ANOVA STATISTICS } & \multicolumn{4}{|c|}{ DESCRIPTIVES } \\
\hline $\begin{array}{l}\text { Independent } \\
\text { variable }\end{array}$ & & $\begin{array}{ll}\begin{array}{l}\text { Sum } \\
\text { squares }\end{array} & \text { of }\end{array}$ & Df & $\begin{array}{l}\text { Mean } \\
\text { squares }\end{array}$ & $\begin{array}{l}\mathrm{F}- \\
\text { value }\end{array}$ & $\begin{array}{l}\mathrm{P} \\
\text { value }\end{array}$ & & & & \\
\hline \multirow{7}{*}{$\begin{array}{l}\text { Level of } \\
\text { education }\end{array}$} & \multirow{3}{*}{$\begin{array}{l}\text { Between } \\
\text { Groups }\end{array}$} & \multirow[t]{3}{*}{613.173} & \multirow[t]{3}{*}{4} & \multirow[t]{3}{*}{153.293} & \multirow[t]{7}{*}{0.870} & \multirow[t]{7}{*}{0.484} & Group & $\mathbf{N}$ & Mean & S. D \\
\hline & & & & & & & $\begin{array}{ll}\text { Form } & 4 \\
\text { leaver } & \end{array}$ & 8 & 139.00 & 6.44 \\
\hline & & & & & & & P1 course & 50 & 137.72 & 14.67 \\
\hline & \multirow{3}{*}{$\begin{array}{l}\text { Within } \\
\text { Groups }\end{array}$} & \multirow[t]{3}{*}{19201.950} & \multirow[t]{3}{*}{109} & \multirow[t]{4}{*}{176.165} & & & Diploma & 37 & 137.35 & 11.89 \\
\hline & & & & & & & Degree & 16 & 135.69 & 14.76 \\
\hline & & & & & & & Masters & 3 & 151.00 & 1.00 \\
\hline & Total & 19815.123 & 113 & & & & Total & 114 & 137.75 & 13.24 \\
\hline
\end{tabular}

Table 6 above shows the computer attitude among primary school teachers of different educational level. Descriptive statistics in Table 6 seems to indicate that computer attitude increases with the level of education attained. Teachers with master degree had the highest computer attitude (mean of 151.00) while those with only Form 4 level had the lowest mean of 139.0. However, ANOVA statistics indicates that there was no significant 
difference in computer attitude with the level of education attained (F value, 0.870 and $\mathrm{p}-\mathrm{value}$ of 0.484 ). This means that as teachers acquire more education they develop positive attitude towards computer.

Table 7. Teaching Experience difference and computer attitude

\begin{tabular}{|c|c|c|c|c|c|c|c|c|c|c|}
\hline & \multicolumn{6}{|c|}{ ANOVA STATISTICS } & \multicolumn{4}{|c|}{ DESCRIPTIVES } \\
\hline $\begin{array}{l}\text { Independent } \\
\text { variable }\end{array}$ & & $\begin{array}{l}\text { Sum of } \\
\text { squares }\end{array}$ & Df & $\begin{array}{l}\text { Mean } \\
\text { squares }\end{array}$ & $\begin{array}{l}\mathrm{F} \quad- \\
\text { value }\end{array}$ & $\begin{array}{l}\mathrm{P}- \\
\text { value }\end{array}$ & & & & \\
\hline \multirow{6}{*}{$\begin{array}{l}\text { Teaching } \\
\text { Experience }\end{array}$} & \multirow{3}{*}{$\begin{array}{l}\text { Between } \\
\text { Groups }\end{array}$} & \multirow[t]{3}{*}{495.429} & \multirow[t]{3}{*}{3} & \multirow[t]{3}{*}{165.143} & \multirow[t]{6}{*}{0.940} & \multirow[t]{6}{*}{0.424} & Group & $\mathbf{N}$ & Mean & S. D \\
\hline & & & & & & & $\begin{array}{l}\text { Less than } \\
2 \text { yrs }\end{array}$ & 10 & 133.40 & 12.89 \\
\hline & & & & & & & $2-5 \mathrm{yrs}$ & 27 & 140.85 & 9.86 \\
\hline & \multirow{2}{*}{$\begin{array}{l}\text { Within } \\
\text { Groups }\end{array}$} & \multirow[t]{2}{*}{19319.694} & \multirow[t]{2}{*}{110} & \multirow[t]{2}{*}{175.634} & & & $6-10 y r s$ & 27 & 136.44 & 16.71 \\
\hline & & & & & & & $\begin{array}{ll}\text { More } & \\
\text { than } & 10 \\
\text { yrs } & \\
\end{array}$ & 50 & 137.66 & 12.81 \\
\hline & Total & 19815.123 & 113 & & & & Total & 114 & 137.75 & 13.24 \\
\hline
\end{tabular}

Table 7 shows the computer attitude among the primary school teacher with different teaching experience. The descriptive statistics in Table 7 shows that teachers with a teaching experience of $2-5$ years had the highest mean of 140.85 while those with less than 2 years had the least mean of 133.40. However, the ANOVA statistics in Table 7 reveal that there is no significant difference between computer attitude and teaching experience among the primary school teachers.

Table 8. Difference in current course undertaken and computer attitude

\begin{tabular}{|c|c|c|c|c|c|c|c|c|c|c|}
\hline & \multicolumn{6}{|c|}{ ANOVA STATISTICS } & \multicolumn{4}{|c|}{ DESCRIPTIVES } \\
\hline $\begin{array}{l}\text { Independent } \\
\text { variable }\end{array}$ & & $\begin{array}{ll}\begin{array}{l}\text { Sum } \\
\text { squares }\end{array} & \text { of } \\
\end{array}$ & Df & $\begin{array}{l}\text { Mean } \\
\text { squares }\end{array}$ & $\begin{array}{l}\mathrm{F}- \\
\text { value }\end{array}$ & $\begin{array}{l}\mathrm{P} \quad- \\
\text { value }\end{array}$ & & & & \\
\hline \multirow{6}{*}{$\begin{array}{l}\text { Current course } \\
\text { pursued }\end{array}$} & \multirow{3}{*}{$\begin{array}{l}\text { Between } \\
\text { Groups }\end{array}$} & \multirow[t]{3}{*}{1877.796} & \multirow[t]{3}{*}{3} & \multirow[t]{3}{*}{625.932} & \multirow[t]{6}{*}{3.839} & \multirow[t]{6}{*}{0.012} & Group & $\mathbf{N}$ & Mean & S. D \\
\hline & & & & & & & None & 69 & 134.62 & 14.90 \\
\hline & & & & & & & Diploma & 19 & 143.42 & 7.77 \\
\hline & Within & 17937.327 & 110 & 163.067 & & & Degree & 23 & 141.09 & 8.87 \\
\hline & Groups & & & & & & Masters & 3 & 148.33 & 3.79 \\
\hline & Total & 19815.123 & 113 & & & & Total & 114 & 137.75 & 13.24 \\
\hline
\end{tabular}

Table 8 shows the difference in computer attitude among the primary school teachers and the courses they were pursuing. Descriptive statistics reveal that teachers who were not pursuing any course had the least mean of 134.62 but those pursuing masters degree had the highest mean of 148.75. ANOVA statistics indicates that the differences are significant ( $\mathrm{p}$ - value of 0.012), at 0.05 significant level. The results mean that as teachers progressed in their education level they develop more positive attitude towards computers.

\section{Conclusion}

The findings in this study show that primary school teachers have positive attitudes toward computers. This means that the teachers have a lot of enthusiasm for computers. This is quite encouraging as it has been realized that computer attitudes influence not only the acceptance of computers, but also their use as professional tools or as teaching/learning aids (Kadijevich, 2002). In addition, the teachers perceive the computer as more of a positive tool that can enhance teaching and learning process. Therefore, to have computers widely used in 
primary school classrooms, efforts should be geared towards reinforcing the existing positive attitudes. More opportunities for teachers to use computers should be provided as frequently as possible.

The teachers' working experience with computers is very low. This was reflected in computer confidence subscale. This, therefore, means that a concerted effort to develop the ability to use or learn about computers is necessary. Measures should be taken to ensure that teachers are given more exposure to hands-on experience on using computers. This can be achieved by organizing training sessions or workshops for the teachers.

The primary school teachers, despite their differences in gender, age, teaching experience and level of education, did not differ significantly (in statistical sense) in their computer attitude. However, younger teachers appeared to be more optimistic.

\section{Recommendations}

Based on the findings of this research, the following are some recommendations: This study highlights the importance of uplifting teachers' confidence level in using computers. If teachers are confident in using the technology, it is predicted that their attitudes toward computer will also rise.

The research utilized data collected from teachers teaching in a rural setting. The findings of this study therefore can only be generalized for a similar group of teachers. It would be worthwhile to include teachers from urban setting as well, and compare whether there are significant differences in the attitudes of teachers who are teaching in the rural and urban areas. Perhaps the data obtained may show at least differences in terms of their experience and computer confidence.

It is also recommended that in addition to the survey method, researchers can shed more light on the complex nature of attitudes, by interviewing the subjects. Reasons behind certain kind of attitudes can also be explained by open-ended type of questions, instead of the Likert-type items used to measure attitudes in this study.

Studying attitudes toward computer among teachers are critical for the successful implementation of computer and information technology in the classroom. Findings of such studies would determine the proper direction toward the success of technology integration in the classroom. Additionally the instilling of positive attitude toward computers would assist the nation to achieve its goal of an information literate society that is able to keep abreast with the latest technology development.

\section{References}

[1] Aiken, L. R. (1980). Attitude measurement and research. In D.A. Payne (Ed.), Recent developments in affective measurement. San Francisco: Jossey- Bass.

[2] Cambre, M.A. and Cook, D.L. (1985). Computer anxiety: Definition, Measurement , and Correlates. Journal of Educational Computing Research, 1:1, 37-54. https://doi.org/10.2190/FK5L-092H-T6YB-PYBA

[3] De Young, C. G., \& Spence, I. (2004). Profiling information technology users: En route to dynamic personalization. Computers in Human Behavior, 20, 55-65.

[4] Fishbein, M. and Ajzen, I. (1975). Belief, Attitude, Intentions and Behaviors: An Introduction to Theory and Research. Boston, MA: Addison-Wesley.

[5] Fletcher, W. E. \& Deeds, J. P. (1994). Computer anxiety and other factors preventing computer use among United States secondary agricultural educators. Journal of Agricultural Education, 35(2), 16-21.

[6] Gibson, J. L., Ivancevich, J.M., and Donnelly, J.H. (1991). Organizational Behavior, Boston: IRWIN, Inc. 
[7] Gressard, C.P. and Loyd, B.H. (1986). Validation studies of a new computer attitude scale. Association for Educational Data Systems, 19, 295-301.

[8] Griffin, J. (1988). CAL Innovation as Viewed by Purchasers of Computer Software in Secondary Schools. Journal of Computer Assisted Learning, Vol. 4, No 3, pp. 150-161.

[9] Igbaria, M. (1993). User Acceptance of Microcomputer Technology: An Empirical Test. OMEGA Int'l Journal of Management Science, 21:1, 73-90.

[10] Kadijevich, D. J. (2002). Four Critical Issues of Applying Educational Technology Standards to Professional Development of Mathematics Teachers. Proceedings of the 2nd International Conference on the Teaching of Mathematics at the undergraduate level. University of Crete.

[11] Kluever, R., Lam, T., Hoffman, E., Green, K. and Swearingen, D. (1994). The Computer Attitude Scale: Assessing Changes in Teachers' Attitudes toward Computers. Journal of Educational Computing Research, Vol. 11, No 3, pp. 251-61.

[12] Krech, D., Crutchfield, R.S., and Ballackey E.L. (1962). Individual in Society. New York, NY: McGraw-Hill.

[13] Loyd, B. H., Loyd, D. E. (1985). The reliability and validity of an instrument for the assessment of computer attitudes. Educational and Psychological Measurement 45(4):903-908.

[14] Loyd, B. H., \&Gressard, C. (1984). Reliability and factorial validity of computer attitude scales. Educational and Psychological Measurement, 44, 501- 505.

[15] Nickerson, R.S. (1981). Why Interactive Computer System Are Sometimes Not Used By People Who Might Benefit From Them. International Journal of Man Machine Studies, 15:4, 469-483.

[16] Pope-Davis , D. B. \& Twing, J. S. (1991). The Effects of Age, Gender and Experience on the Measure of Attitude Regarding Computers. Computer in Human Behavior, 7, 333 - 339.

[17] Ray, C. M., Sormunen, C., \& Harris, T. M. (1999). Men's and Women's Attitudes Toward Computer Technology: A Comparison. Office Systems Research Journal, 17(1), 1-8.

[18] Rosenberg, M.J. (1960). A Structural Theory of Attitudes. Public Opinion Quarterly, 319-340.

[19] Saade, R. G., \& Galloway, I. (2005). Understanding Intention to Use Multimedia Information Systems for Learning. Issues in Informing Science and Information Technology, 287-295.

[20] Thompson, R.L., Higgins, C.A., and Howell, J.M. (1991). Personal Computing: Toward a Conceptual Model of Utilization. MIS Quarterly, 15:1, 125-143.

[21] Triandis, H.C. (1971). Attitude and Attitude Change. New York, NY: John Wiley and Sons, Inc. Wilson, J.H. and Daubek, H.G. (1992). Computer Attitudes and Marketing Education. Journal of Marketing Education, 14:1, 80-90. Woodrow, J.J. (1991). A Comparison of Four Computer Attitude Scales. Journal of Educl. Computing Research, 7, 165-187. 
[22] Kenyatta, U. (2003). Speech Delivered during the State Opening of the 11th Parliament on Tuesday, 16th April, 2013. Retrieved from: http://www.capitalfm.co.ke/eblog/2013/04/16/president-uhurusspeech-during-official-opening-of-11th-parliament/.

[23] Yuen, A. H. K. \& Ma, W. K. (2001). Teachers' Computer Attitudes: Factors influencing the Instructional Use of Computers. Proceedings of the International Conference on Computers in Education, November 2001, Korea, 7p.

[24] Yushau, B. (2006). Computer attitude, use, experience, software familiarity and perceived pedagogical usefulness: The case of mathematics professors. Eurasia Journal of Mathematics, Science and Technology Education, 2(3), $1-7$. 